\title{
Notes on Ipomoea (Convolvulaceae) from the Amazonian periphery
}

\author{
J. R. I. Wood ${ }^{1,2}$ \& R. W. Scotland ${ }^{1}$
}

Summary. Attention is drawn to the relatively low number of Ipomoea species found in the Amazon basin as well as to the rarity of most species restricted to the region. Six new species from the Amazonian periphery are described: Ipomoea acrensis J. R. I. Wood \& Scotland and I. altoamazonica J. R. I. Wood \& Scotland from Brazil and Peru, I. maranyonensis J. R. I. Wood \& Scotland from Peru, I. macarenaensis J. R. I. Wood \& Scotland from Colombia, I. pogonocalyx J. R. I. Wood \& Scotland from Brazil and I. deminuta J. R. I. Wood \& Scotland from Bolivia. Variation in I. megapotamica is discussed and two subspecies are recognised, subsp. megapotamica from southern South America and subsp. velutina J. R. I. Wood \& Scotland from northern Brazil and Venezuela. Plants treated as I. chenopodiifolia M. Martens \& Galeotti from Venezuela are recognised as I. retropilosa (Pittier) D. F. Austin. Two subspecies of this species are proposed, subsp. retropilosa being endemic to the Venezuelan Andes whereas the newly described subsp. cundinamarcana J. R. I. Wood \& Scotland is restricted to Colombia. I. austinii Infante-Bet. is treated as a synonym of the African I. involucrata P. Beauv., one of a number of Old World species now established in the neotropics.

Key Words. Amazon, Bolivia, Brazil, Colombia, introductions, Peru, rainforest, taxonomy, variation, Venezuela.

\section{Introduction}

Ipomoea is widely distributed in tropical and subtropical America and is often a conspicuous feature of roadsides, scrub, forest margins, swamp and savanna. However, our studies show that it is less diverse in the Amazonian rain forest than might be expected. There are a few widely distributed rainforest species which occur. Some of these are relatively frequent, such as I. batatoides Choisy and I. philomega (Vell.) House, and a few others are quite widespread but uncommon such as I. amazonica (D. F. Austin \& Staples) J. R. I. Wood \& Scotland (Map 1) or I. eriocalyx (Kuntze) (Mart. ex Choisy) Meisn. However, most species of Ipomoea recorded from moist forest are either widespread weedy species of disturbed areas or very localised species endemic to the Amazon basin often being known from a very few specimens from one or two locations. Amongst the few species hitherto known from this latter category are I. spruceana Meisn. and I. marabaensis D. F. Austin, to which this paper adds another six, all of which demonstrate a very restricted distribution around the periphery of the Amazon basin.

\section{Materials and Methods}

This publication is one of the fruits of ongoing monographic studies being carried out into the genus Ipomoea at the Department of Plant Sciences, University of Oxford. These particular results are based mainly on the examination of material from a range of different herbaria visited by the first author during 2013 - 15 when unidentified material was picked out for further study. Most of this was subsequently sent on loan to Oxford through the collaboration of curators in the different institutions listed in the acknowledgements. We have also made extensive use of a range of images now available on line from different herbaria, especially $\mathrm{C}$, COL, G, M, P, RB, SI and VEN, in many cases directly from the virtual herbaria of the individual herbaria but also through the extensive range of type material available through Jstor (www.jstor.org/). Although most of the specimens cited here are relatively old and have proved unsuitable for molecular sequencing, we have been able to suggest relationships with a degree of confidence based on our molecular studies (Muñoz et al. in prep.) and the obvious morphological characters. Species delimitation has inevitably been based almost entirely on the morphological characteristics of the specimens we have seen.

\section{Ipomoea amazonica}

Ipomoea amazonica (D. F. Austin E Staples) J. R. I. Wood Ẽ Scotland (Wood et al. 2015: 27).

Accepted for publication 7 February 2017. Published online 24 March 2017

1 Department of Plant Sciences, University of Oxford, South Parks Road, Oxford, OX1 3RB, UK.

2 Royal Botanic Gardens, Kew, Richmond, Surrey, TW9 3AB, UK. e-mail: jriwood@hotmail.com 
Turbina amazonica D. F. Austin \& Staples (Austin \& Staples 1991: 270). Type: Brazil, Amapá. D. F. Austin, C. E. Nauman, B. Rabelo, C. Rosario E̊ M. R. Santos 7389 (holotype. MG; isotypes FAU, now at FTG!, NY!, US!).

Calystegia glaziovii Dammer (Dammer 1897: 41), non Ipomoea glaziovii Dammer (1897), synon. nov. Type: Brazil, Minas Gerais, "près de Queluz, dans la forêt," Glaziou 13009 (holotype B†, photo F, isotypes K00612827, P03562329).

NOTE. This species is the most widespread of those endemic to the Amazon basin (Map 1), being found both to the north and to the south of the Amazon basin and in Bolivia and Colombia as well as Brazil. Its distribution strongly suggests that it has been widely overlooked and it could be expected to occur in Peru and Venezuela and possibly also in Ecuador, Guyana and Guyane Française. It illustrates well the patchy knowledge we have of the distribution of most Amazonian species.

The Minas Gerais locality cited for Glaziou 13009 appears improbable but not impossible.

\section{Six localised new species}

Ipomoea acrensis J. R. I. Wood E Scotland, sp. nov. Type: Brazil, Acre, Mun. de Río Branco, Apa do Ireneu Derra, 9 $56^{\prime} 03^{\prime \prime S} 67^{\circ} 52^{\prime} 08^{\prime \prime} \mathrm{W}, 12$ July 2007,
C. S. Pessoa, E. Consuelo, I. E. S. Moll, P. Palhares, Adriana F. Obermüller, M. Silveira, I. M. Saar E̋ W. Castro 302 (holotype RB).

http:/ /www.ipni.org/urn:lsid:ipni.org:names:60473766-2

Twining perennial, "liana" (fide Pessoa et al. 302) of unknown height; stems glabrous, somewhat woody. Leaves petiolate, $6-16 \times 5-12 \mathrm{~cm}$, ovate, shortly acuminate to a fine point, cordate, the auricles rounded or acute, margin undulate, often irregularly dentate, glabrous, paler beneath, thin in texture, main veins abaxially prominent; petioles $9.5-11 \mathrm{~cm}$, glabrous. Inflorescence of up to 7-flowered, axillary, pedunculate compound cymes, glabrous; peduncles $12-15 \mathrm{~cm}$, stout, woody; bracteoles not seen, caducous; secondary and tertiary peduncles c. 2.5 $\mathrm{cm}$; pedicels $2.3-6.5 \mathrm{~cm}$, conspicuously thickened upwards; sepals slightly unequal, outer $18-22 \times 10-12$ $\mathrm{mm}$, narrowly oblong-elliptic, acute or obtuse, mucronate, inner sepals very slightly shorter, pale green; corolla c. $10-11 \mathrm{~cm}$ long, glabrous, pale blue, narrowly funnelshaped, the tube c. $2 \mathrm{~cm}$ wide for $5-7 \mathrm{~cm}$, then widened to c. $3 \mathrm{~cm}$; limb 5-6 cm diam., apparently lobed. Capsule and seeds not seen. Fig. 1.

RECOGNITION. This species is obviously close to Ipomoea clavata (G. Don) Oostst. ex J. F. Macbr. and appears to be similar in habit, corolla shape and corolla colour although we have seen no photographs of living plants. However, it differs significantly in being

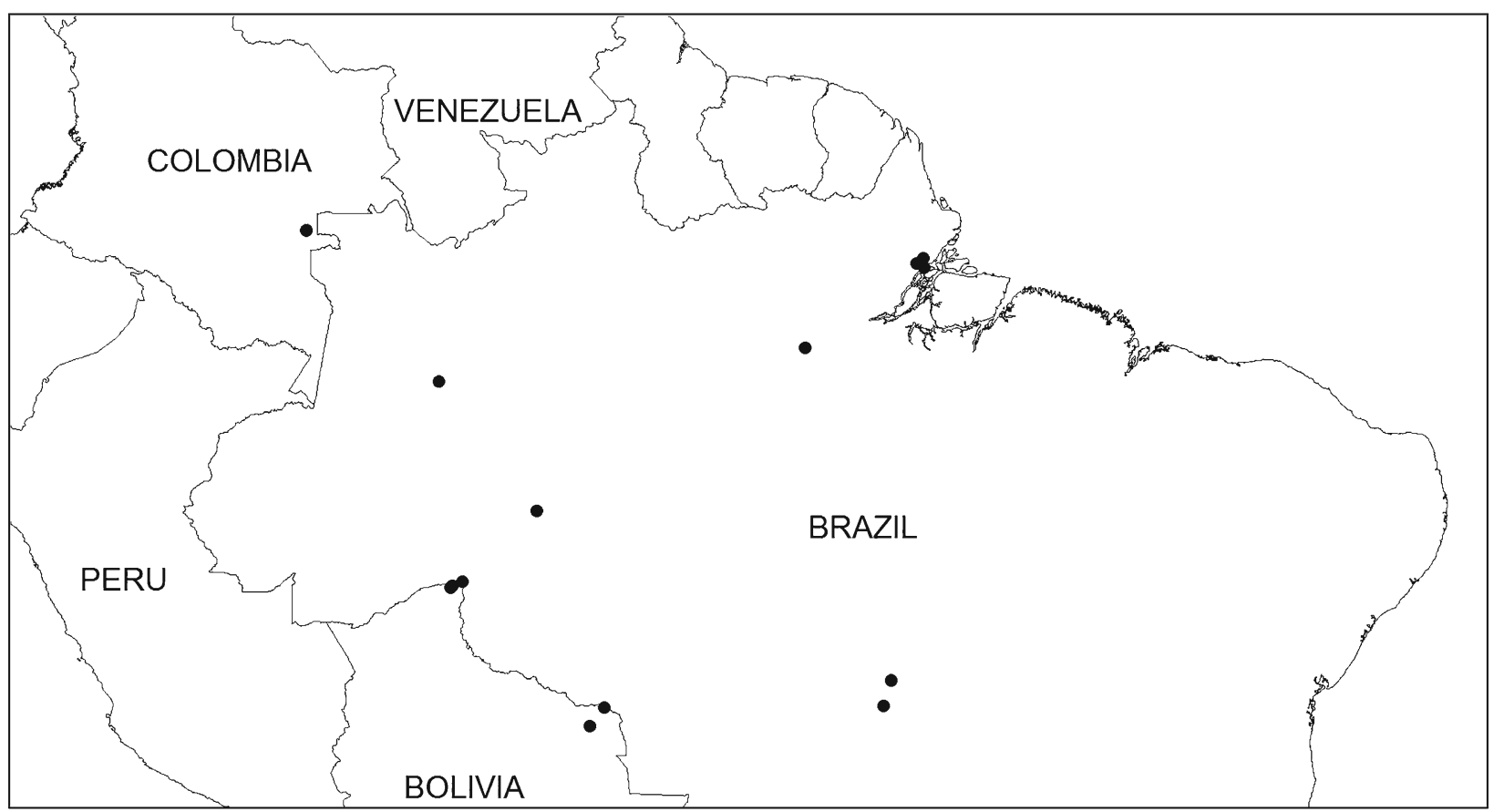

Map 1. Distribution of Ipomoea amazonica $(\bullet)$. A widely distributed Amazonian species which illustrates the patchy nature of Amazonian records. 


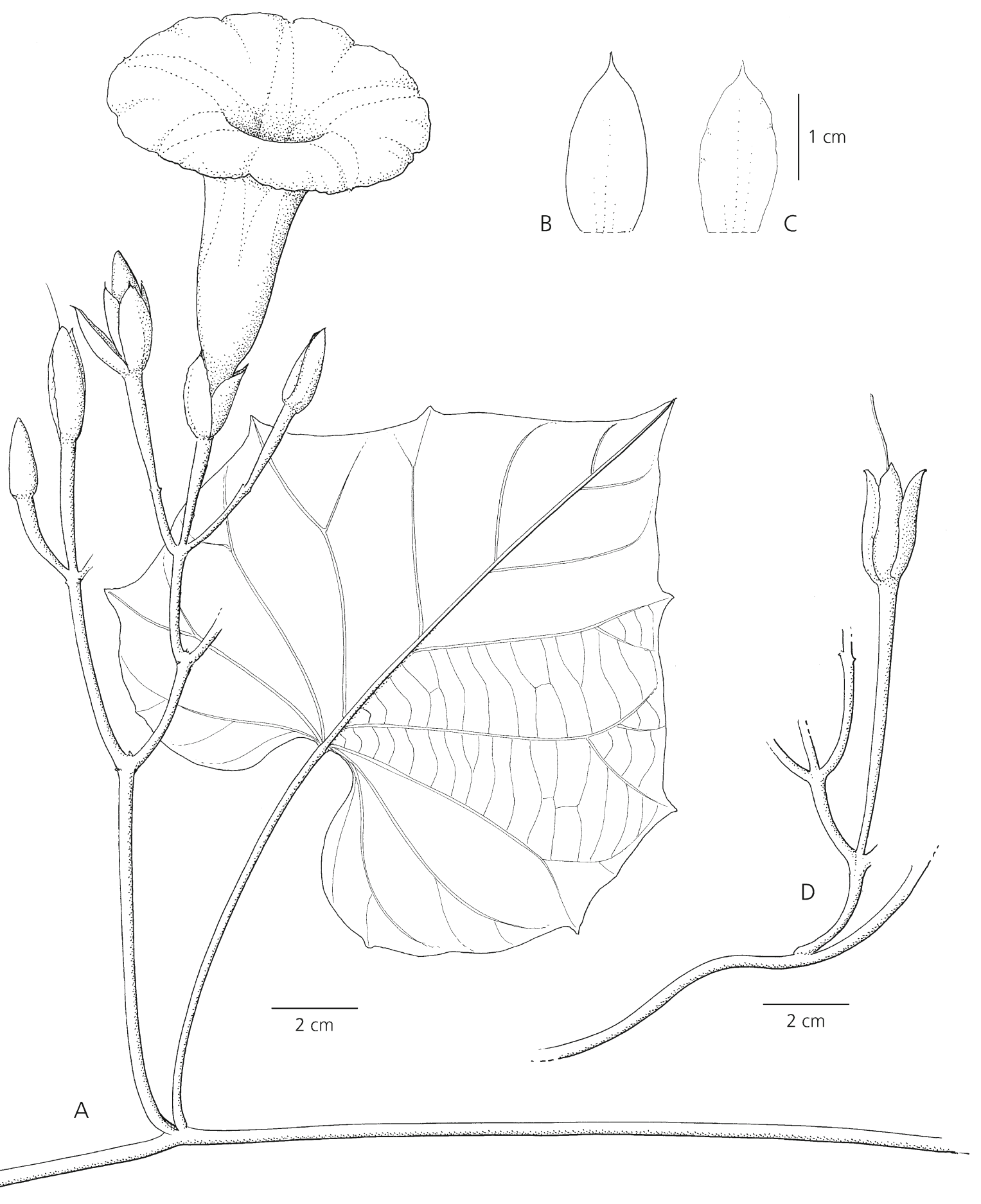

Fig. 1. Ipomoea acrensis. A habit; B outer sepal; C inner sepal; D fruiting calyx. A from Pessoa et al. 302, B - C from M. Alexiades \& A. Byrne 865, D from A. Gentry et al. 37636. DRAWN BY ROSEMARY WISE.

entirely glabrous and lacks the long, white spreading hairs so characteristic of the stems of I. clavata. The inflorescence is long pedunculate, the peduncles up to $15 \mathrm{~cm}$ in length, whereas in I. clavata they are only $2.5 \mathrm{~cm}$ long. Additionally the cymes are up to 7flowered whereas in I. clavata the flowers are usually solitary, rarely up to 3 together.
HABITAT \& DISTRIBUTION. Upper Amazon region in Brazil and Peru (Map 2). Although not clearly specified by collectors, it is apparently a plant of disturbed areas derived from moist lowland rain forest.

SPECIMENS EXAMINED. BRAZIL. Acre: Mun. de Rio Branco, Apa do Ireneu Serra 956'03"S 6752'08"W, 12 July 2007, C. S. Pessoa et al. 302 (holotype RB). PERU. 
Huanuco: $69 \mathrm{~km}$ NE of Tingo Maria in disturbed roadside forest on road to Tocache, Huallaga valley, $9^{\circ} 00^{\prime} \mathrm{S} 76^{\circ} \mathrm{W}$, 550 m, 16 July 1982, A. Gentry et al. 37636 (FTG, MO). Madre de Dios: Tambopata, in well-lit bamboo forest in very moist subtropical forest, confluence of rivers Tambopata and Chuncho, $13^{\circ} 20^{\prime} \mathrm{S} 69^{\circ} 60^{\prime} \mathrm{W}, 400 \mathrm{~m}, 22$ July 1989, M. Alexiades E̋ A. Byme 865 (NY).

CONSERVATION STATUS. Based on its area of occupancy of approximately $12,000 \mathrm{~km}^{2}$, it could be categorised as Endangered (EN), but with only three records and an area of occurrence of almost $190,000 \mathrm{~km}^{2}$, it should be treated provisionally as Data Deficient (DD). The existence of only three widely separated records gives little indication of its true frequency (Map 2).

ETYMOLOGY. This species is named after Acre State, from where the type was collected, itself named after the Río Acre a tributary of the Amazon.

Ipomoea altoamazonica $J$. R. I. Wood E Scotland, sp. nov. Type: Peru, Cusco, Paucartambo, Chontachaka a Pillahuata, 700 m, P. Nuñez 8087 (holotype MO).

http:/ /www.ipni.org/urn:lsid:ipni.org:names:77160006-1

Twining perennial herb $1-2 \mathrm{~m}$ high, growing over shrubs; stems pilose. Leaves petiolate, $7-11 \times 7-9.5 \mathrm{~cm}$, 3-lobed to half way or slightly less, base cordate with rounded auricles, lobes ovate, apex shortly acuminate and mucronate, both surfaces densely pubescent with long, somewhat asperous hairs; petioles $4-12 \mathrm{~cm}$, pilose.
Inflorescence of up to 5-flowered axillary cymes; peduncles $1.3-5.3 \mathrm{~cm}$, pilose; bracteoles $3-11 \times 0.5-1 \mathrm{~mm}$, filiform to linear, pilose; secondary peduncles (if present) $8-10 \mathrm{~mm}$; pedicels $22-33 \mathrm{~mm}$, pilose; sepals unequal, outer $14-17 \times 5-6 \mathrm{~mm}$, oblong-ovate, obtuse, mucronate, abaxially covered in scattered long white hairs mixed with soft spines, both $3-4 \mathrm{~mm}$ long, inner sepals $10-12 \times 4-5 \mathrm{~mm}$, ovate, mucronate, glabrous and spineless, margins scarious; corolla $5 \mathrm{~cm}$ long, funnel-shaped, white, glabrous; limb c. $4 \mathrm{~cm}$ diam. Capsule and seeds not seen. Fig. 2.

RECOGNITION. This species clearly forms a group of three species with Ipomoea echinocalyx Meisn. and I. crinicalyx $\mathrm{S}$. Moore. The group is easily recognised by the fleshy spines that cover most of the surface of the outer sepals but which are absent from other vegetative parts. All three are clearly closely related but occupy different geographical areas, I. altoamazonica being the only species found in Peru and adjacent parts of Amazonian Brazil. It is immediately distinguished from the other two species by the 3-lobed leaves (entire in the other two species). From I. echinocalyx it is also distinguished by the relatively long peduncles (up to 5.3 $\mathrm{cm}$, not $<0.5 \mathrm{~cm}$ ), which bear up to 5 flowers, rather than a single or (rarely) $2-3$ flowers. From I. crincicalyx it is distinguished by the white (not pink) flowers and the pilose indumentum of the stem, leaves, peduncles and sepals. I. crinicalyx is glabrous or puberulent.

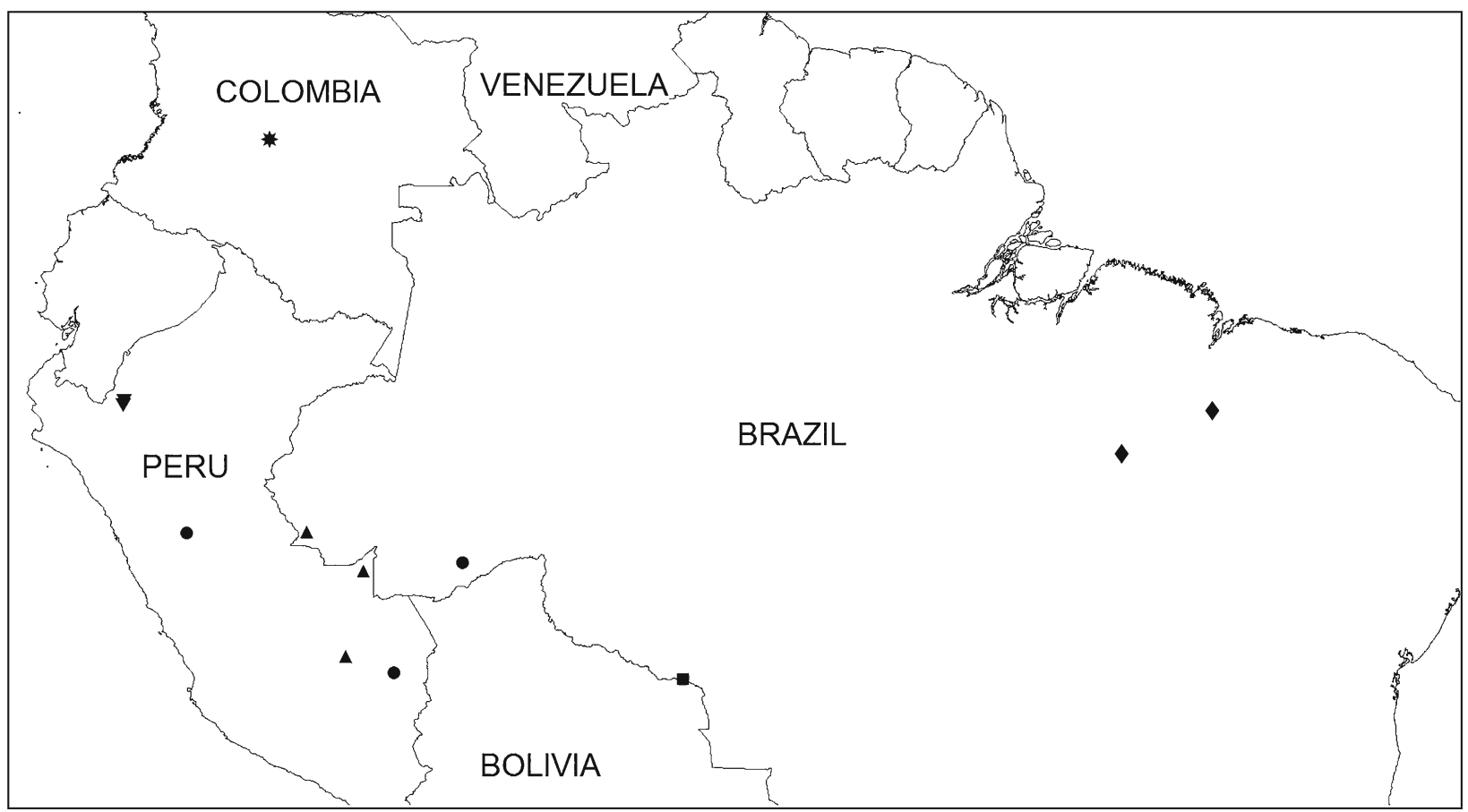

Map 2. Distribution of six new species from the periphery of the Amazon basin: Ipomoea acrensis (•), I. altoamazonica ( $\mathbf{\Delta}$ ), I. maranyonensis ( $\mathbf{\nabla})$, I. macarenensis (*), I. pogonocalyx ( $\bullet$, I. deminuta (घ). 


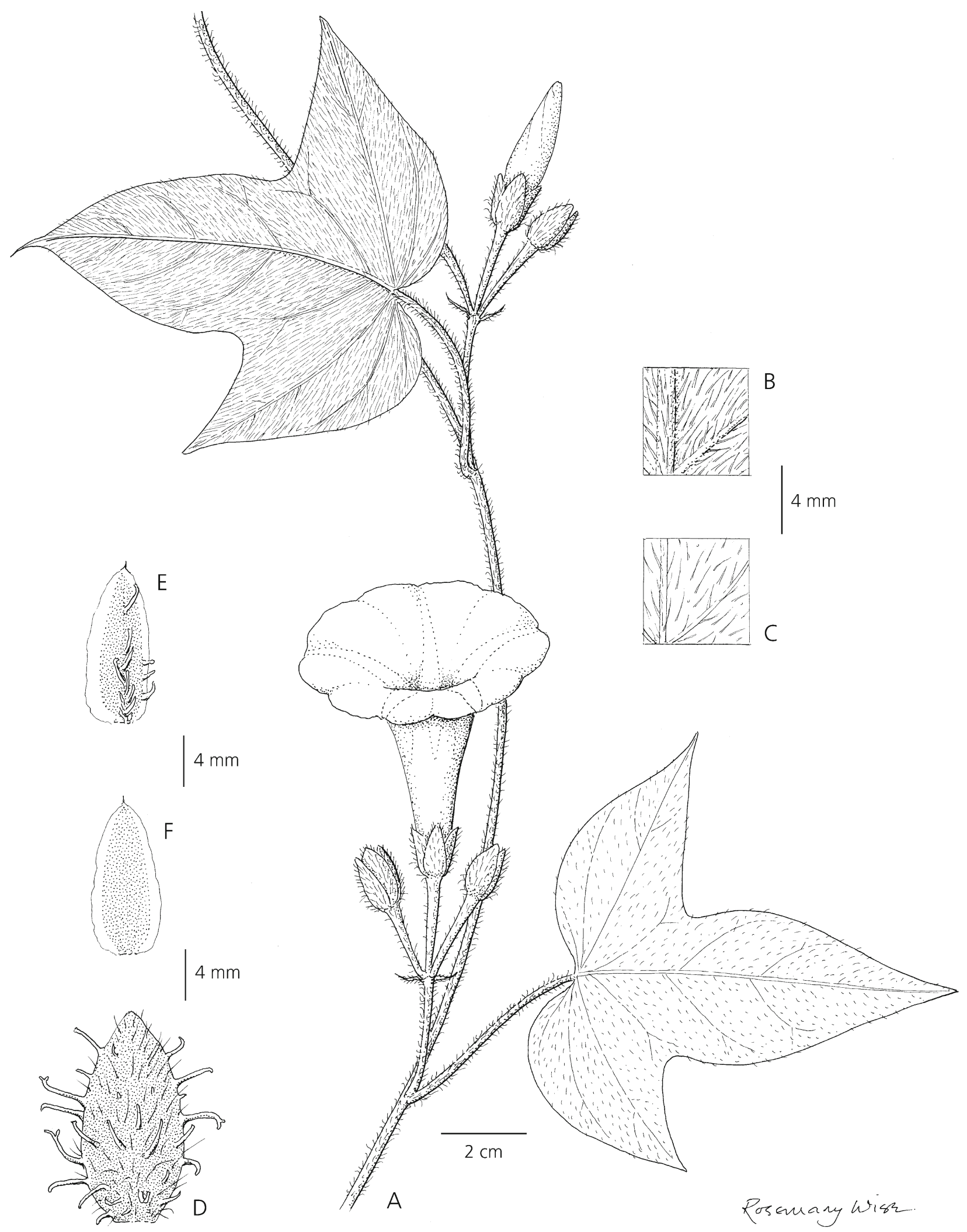

Fig. 2. Ipomoea altoamazonica. A habit; B adaxial leaf surface; C abaxial leaf surface; D outer sepal; E middle sepal; $F$ inner sepal. A from D. C. Daly et al. 10707; B - C from D. C. Daly et al. 15012; D - F from Percy Nuñez 887. DRAWN BY ROSEMARY WISE.

HABITAT \& DISTRIBUTION. A plant of lowland forest areas endemic to the upper Amazon watershed on the borders of Peru and
Brazil, found in secondary forest with abundant light (Shunke EF Graham 15012) and in cloud forest (Nuñez 8087) (Map 2). 
SPECIMENS EXAMINED. BRAZIL. Acre: Marechal Thaumaturgo, basin of Rio Jurúa, Rio Tejo, left bank, 8 59'30S 7241'28W, 28 April 2001, D. C. Daly et al. 10707 (ARIZ). PERU. Cusco: Prov. Paucartambo, Chontachaca a Pillahuata, $700 \mathrm{~m}, 10$ May 1987, P. Nuñez 8087 (holotype MO). Ucayali: Prov. Purús, $8 \mathrm{~km}$ debajo del Puerto Esperanza, margen derecho del Río Purús, 150 - 190 m, 10²'S 7057'W, 12 March 2002, J. Schunke V. Eं J. G. Graham 15012 (ARIZ).

CONSERVATION STATUS. Based on its area of occupancy of approximately $12,000 \mathrm{~km}^{2}$, it could be categorised as Endangered (EN), but with only three records and an area of occurrence of over $32,000 \mathrm{~km}^{2}$, it should be treated provisionally as Data Deficient (DD). The existence of only three widely separated records gives little indication of its true frequency (Map 2).

Ipomoea maranyonensis J. R. I. Wood E Scotland, sp. nov. Type: Peru, Amazonas, Prov. Bagua, Imaza Distr., Com. Yamayakat, R. Vásquez, A. Peña E E. Chávez 23929 (holotype FTG; isotype MO).

http://www.ipni.org/urn:lsid:ipni.org:names:60473767-2

Liana of unknown height, apparently glabrous in all parts. Leaves petiolate, $5.5-10 \times 7-8 \mathrm{~cm}, 3-5$-lobed to near the base, the 4 th and 5 th lobes often only partially developed, lobes oblong-elliptic or lanceolate, 0.5 $2.5 \mathrm{~cm}$ wide, acuminate, base truncate, abaxially paler; petioles $4-6 \mathrm{~cm}$. Inflorescence of compounded axillary cymes, 20 - 30 cm long; peduncles 9 - 12 cm long; 2nd 6 th degree peduncles $1-4 \mathrm{~cm}$; bracteoles $1 \mathrm{~mm}$, oblong, scale-like, deciduous; pedicels $7-11 \mathrm{~mm}$; sepals subequal, $5-7 \times 2.5-4 \mathrm{~mm}$, elliptic, coriaceous, concave, outer rounded, minutely mucronate, inner \pm scarious, rounded; corolla $4 \mathrm{~cm}$ long, pink, funnelshaped, glabrous; limb c. $2.5 \mathrm{~cm}$ diam., the midpetaline bands ending in teeth; stamens included, longer filaments c. $15 \mathrm{~mm}$, shorter c. $8 \mathrm{~mm}$, anthers oblong, $3 \mathrm{~mm}$ long; style $2.3 \mathrm{~cm}$, glabrous; stigma biglobose. Capsule $6 \times$ $4 \mathrm{~mm}$, ovoid with a slender persistent style, glabrous; seeds (possibly immature) $3 \times 1.5 \mathrm{~mm}$, pilose with long white hairs on the angles. Fig. 3.

RECOGNITION. This species belongs to the distinctive clade with coriaceous, somewhat concave sepals of which Ipomoea mauritiana Jacq. is the best-known and most widespread species. It has indeed been identified as $I$. mauritiana but is immediately distinguished by the compound axillary inflorescences which reach $30 \mathrm{~cm}$ in length and are divided up to six times. Additionally, the sepals, corolla and capsules are all much smaller than in I. mauritiana. In I. maranyonensis the sepals are $5-7 \times 2.5-4 \mathrm{~mm}$, the corolla c. $4 \mathrm{~cm}$ long and the capsule only c. $6 \times 4 \mathrm{~mm}$ whereas in I. mauritiana the sepals are $7-10 \times 5-6 \mathrm{~mm}$, the corolla $5-6 \mathrm{~cm}$ long and the capsule $10-15 \times 6-10 \mathrm{~mm}$.

HABITAT \& DISTRIBUTION. Endemic to "transitional primary forest" in the Marañon Valley of northern Peru (Map 2).

SPECIMENS eXAMINed. PERU. Amazonas: Prov. Bagua; Distr. Imaza, Com. Yamayakat, 503'24"S 78²0'17"W, 600 m, 6 June 1997, R. Vásquez et al. 23929 (holotype FTG; isotype MO); ibid., 455"S 78¹9"W, $320 \mathrm{~m}, 24$ Nov. 1993, R. Vasquez et al. 18569 (FTG, MO).

CONSERVATION STATUS. Based on its very restricted area of occupancy and extent of occurrence this species would be assessed as Critically Endangered (CR). However, in the absence of any detailed understanding of its ecology or of its frequency in the two known populations, any formal categorisation would be premature and it should be categorised as Data Deficient (DD) until detailed studies can be carried out.

ETYMOLOGY. This species is named after the Rio Marañon in northern Peru, which forms a deep dry valley rich in endemic species before disgorging into the Amazon basin.

Ipomoea macarenaensis J. R. I. Wood E Scotland, sp. nov. Type: Colombia, Meta, El Mico airstrip, last savannah before Río Guajar, 6 Nov. 1949, $W . R$. Philipson, J. M. Idrobo Ẽ A. Fernández 1322 (holotype $\mathrm{BM}$; isotypes MO, US).

http:/ /www.ipni.org/urn:lsid:ipni.org:names:77160012-1

Climbing perennial herb of unknown height; stems densely pubescent to subtomentose. Leaves petiolate, $2.5-5.5 \times 2.8$ $-5 \mathrm{~cm}$, ovate, entire or very shallowly $2-3$-lobed, apex acute, mucronate, base truncate to shallowly cordate, adaxially green, thinly adpressed-pilose, abaxially densely silvery-tomentose with rather long appressed hairs; petioles $2-3.8 \mathrm{~cm}$, pubescent. Inflorescence of few-flowered axillary cymes; peduncles $1.2-5 \mathrm{~cm}$; bracteoles $12-20 \times 1$ - $7 \mathrm{~mm}$, linear to oblanceolate-narrowly elliptic, foliose, variable in size and shape; secondary peduncles $6 \mathrm{~mm}$; pedicels $5-6 \mathrm{~mm}$, pubescent; sepals subequal, densely pilose with long spreading hairs, outer $11-14 \times 7-8 \mathrm{~mm}$, ovate, acuminate, inner similar but the margins scarious, glabrous; corolla $5.5-6 \mathrm{~cm}$ long, funnel-shaped, white with pale pink centre, pubescent, limb c. $4 \mathrm{~cm}$ diam., entire, longer filaments c. $25 \mathrm{~mm}$, shorter 12 - $14 \mathrm{~mm}$; style $15 \mathrm{~mm}$ long, glabrous, stigma biglobose. Capsule and seeds not seen. Fig. 4.

RECOGNITION. This species clearly belongs to the radiation of species whose centre of diversity lies in eastern Paraguay. Like others in the clade the corolla and sepals are hirsute. At COL this species has been named Ipomoea tuxtlensis House (= I. peteri (Kuntze) Staples \& Govaerts) but differs in a range of characters 


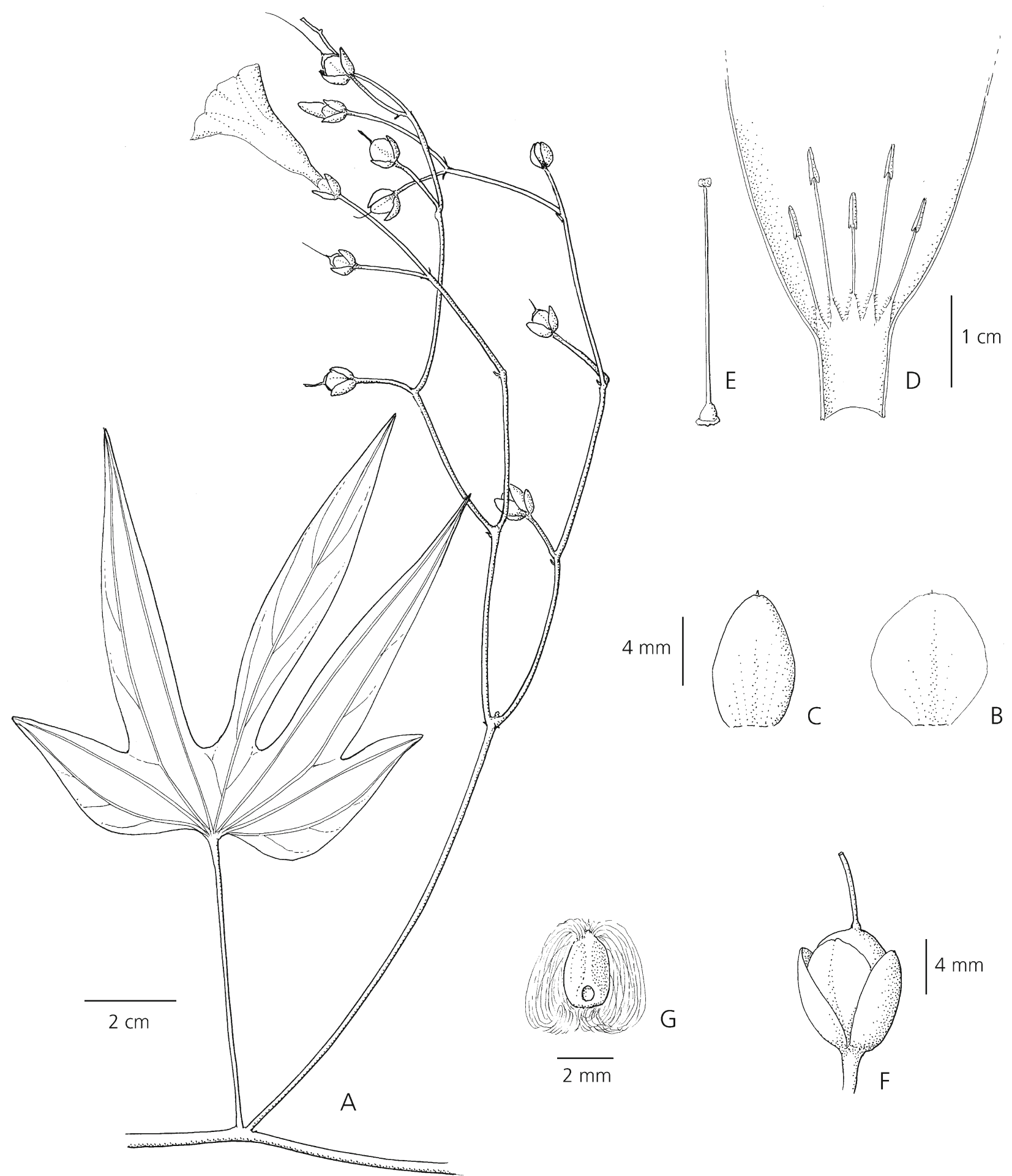

Fig. 3. Ipomoea maranyonensis. A habit; B outer sepal; C inner sepal; D corolla opened out to show stamens; E ovary and style; $\mathrm{F}$ calyx and capsule; G seed. A, F - G from $R$. Vazquez et al. 18569; B - E from $R$. Vazquez 23929. DRAWN BY ROSEMARY WISE.

including leaf shape and leaf indumentum, the much longer peduncles, the foliose bracteoles and acuminate sepals. It has also been identified as I. sericophylla Meisn. and the two species have a very similar leaf indumentum. I. macarenaensis is, however, readily distinguished by the much larger sepals (11 - 14 $\mathrm{mm}$, not $6-8 \mathrm{~mm}$ long), larger corolla $5.5-6 \mathrm{~cm}$, not $4.5 \mathrm{~cm}$ in length, and the much laxer, fewer-flowered cymes with foliose bracteoles. It is also similar to subsp. velutina of $I$. megapotamica but differs in the pilose indumentum of the sepals as well as their much larger size. It is almost certainly closest to I. opulifolia Rusby 

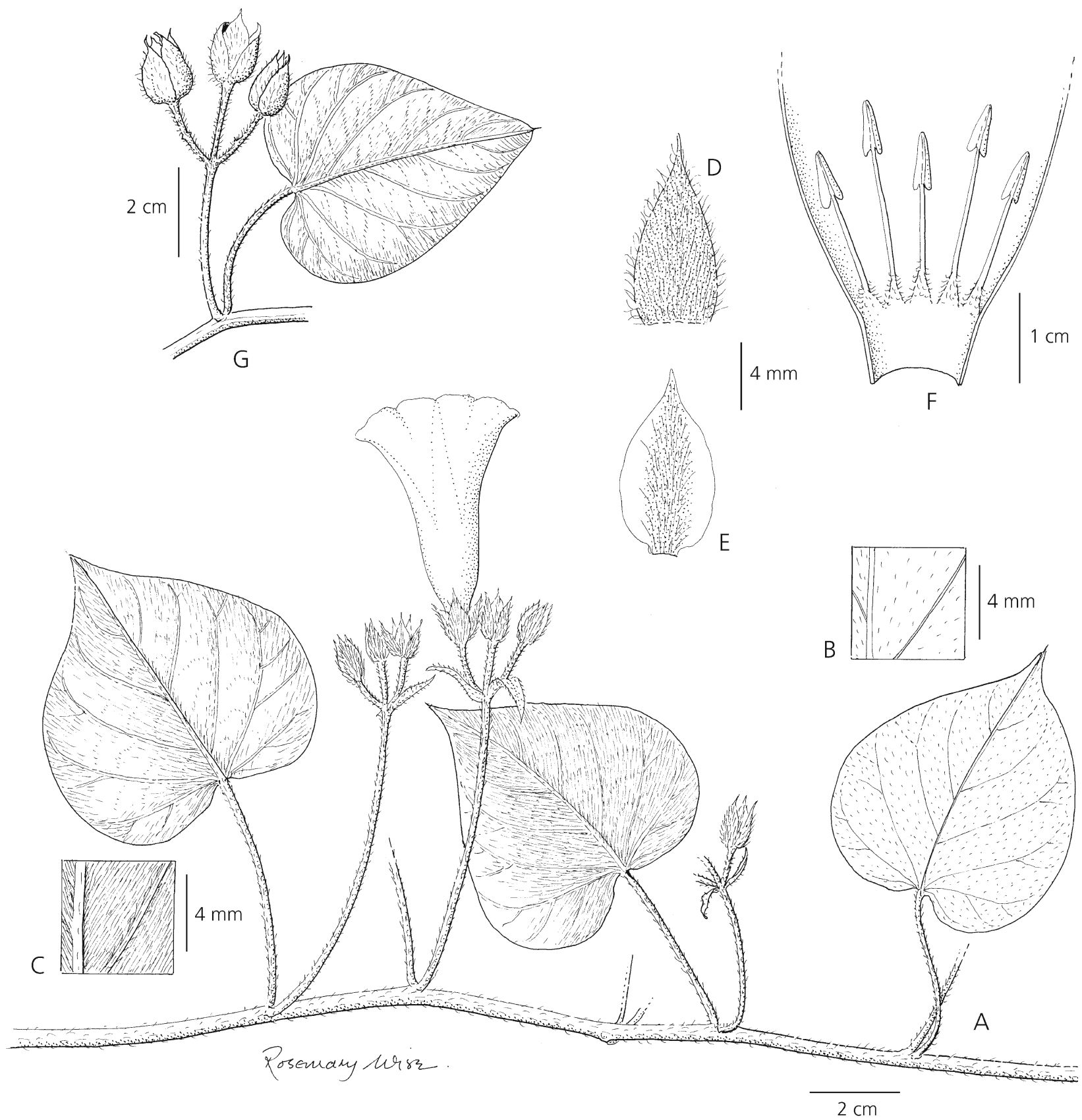

Fig. 4. Ipomoea macarenaensis. A habit; B adaxial leaf surface; C abaxial leaf surface; $D$ outer sepal; $E$ inner sepal; F corolla opened out to show stamens; G fruiting inflorescence. A - C from W. R. Philipson et al. 1322; D - G from J. Cuatrecasas 7778. DRAWN BY ROSEMARY WISE.

but the leaves are unlobed or only shallowly lobed and the sepals distinctly larger $(11-14 \mathrm{~mm}$, not $10-11$ $\mathrm{mm}$ ) and with conspicuous spreading, not appressed hairs. The outer sepals are acuminate, not obtuse. The bracteoles are larger and more persistent than in all these related species.

HABITAT \& DISTRIBUTION. Endemic to Meta Department in Colombia where it grows at low altitudes in llanos (grassy plains) below the Serranía de Macarena (Map 2). SPECIMENS EXAMINED. COLOMBIA. Meta: La Serranía entre los Ríos Ariari y Meta, 240 m, 19 Nov. 1939,
J. Cuatrecasas 7778 (US01123296, COL000104672); El Mico airstrip, last savannah before Río Guajar, 450 m, 6 Nov. 1949, W. R. Philipson, J. M. Idrobo Ė A. Fernández 1322 (holotype BM; isotypes COL000104674, MO, US). CONSERVATION STATUS. Based on its very restricted area of occupancy and extent of occurrence this species would be assessed as Critically Endangered (CR). However, in the absence of any detailed understanding of its ecology or of its frequency in the two populations, any formal categorisation would be premature and it should be categorised as Data 
Deficient (DD) until detailed studies can be carried out.

ETYMOLOGY. This species is named after the Serranía de Macarena in eastern Colombia, a mountain range and national park famous for its biodiversity.

NOTE. While this paper was in proof we have seen two additional specimens, which may represent another species or a variety of Ipomoea macarenaensis. These are Lindman 3189 (S) from Santa Cruz da Barra, Mato Grosso, Brazil and J. P. Coulleri et al. 166 (CTES) from near San Pablo, Marban in the Beni of Bolivia. The two collections are not quite identical but both resemble $I$. macarenaensis in their spreading indumentum and relatively persistent bracteoles but differ in the much smaller sepals and narrower linear bracteoles.

Ipomoea pogonocalyx $J$. R. I. Wood E Scotland, sp. nov. Type: Brazil, Maranhão, Mun. Tuntum, Palmerinha, $74 \mathrm{~km}$ de Tuntum, 27 Feb. 1983, J. U. Santos, E. L. Taylor, G. E. Schotz, N. A. Rosa, C. S. Rosário, T. Rebbeck, J. F. Silva $\mathcal{E}^{\circ}$ M. R. Santos 711 (holotype MG; isotypes FTG, K, NY, US).

http://www.ipni.org/urn:lsid:ipni.org:names:77160013-1

Twining perennial herb to $1.5 \mathrm{~m}$, stem and all vegetative parts hirsute with rather stiff, whitish, spreading bulbousbased hairs. Leaves petiolate, $4-13 \times 3.5-11 \mathrm{~cm}$, ovate, cordate with rounded auricles, margin entire to slightly undulate, apex abruptly acute, both surfaces hirsute but abaxially paler; petioles $1.7-7.5 \mathrm{~cm}$, hirsute. Inflorescence of axillary pedunculate cymes, usually with 5 flowers; peduncles $2.5-8.5 \mathrm{~cm}$, hirsute, appearing somewhat flexuose; bracteoles $3-4 \times 0.5 \mathrm{~mm}$, linear, acuminate, caducous; secondary peduncles $1.3-2.3 \mathrm{~cm}$; pedicels relatively long, $1.6-3.6 \mathrm{~cm}$, slightly more hirsute than peduncles; sepals subequal, $12-15 \times 8-9 \mathrm{~mm}$, coriaceous, concave, ellipticobovate, outer obtuse, abaxially hirsute when young, but hairs somewhat deciduous on the upper part when old, inner sepals rounded, glabrous except for a few hairs near base; corolla $6.5-7 \mathrm{~cm}$, funnel-shaped, pink, glabrous; limb c. $3.5 \mathrm{~cm}$ diam.; stamens included. Capsule and seeds not seen. Fig. 5 .

RECOGNITION. The coriaceous concave sepals of this species clearly indicate that it belongs to the same group of species as Ipomoea mauritiana and I. maranyonensis. It is readily distinguished from other species in this group by the long, somewhat stiff, spreading bulbous-based hairs that cover all vegetative parts including the outer sepals. The rather long pedicels suggest an affinity with $I$. batatoides and also perhaps with an undescribed species from the same region represented by Rosa E Santos 2011 (F, FTG, MG, NY). There is also a resemblance to I. suaveolens
(M. Martens \& Galeotti) Hemsl. from Mesoamerica but the larger sepals and pink, funnel-shaped, not white, tubular corolla serve to distinguish the two species.

HABITAT \& DISTRIBUTION. Endemic to Maranhão State in Brazil, where it is reported from rocky ground in semi-deciduous forest ( $G$. Pereira-Silva $\mathcal{E}$ G. A. Moreira 11328) (Map 2).

SPECIMENS EXAMINED. BRAZIL. Maranhão: Mun, Tuntum, Palmerinha, 74 km de Tuntum, 27 Feb. 1983, J. U. Santos et al. 711 (FTG, K, MG, NY, US); Estreito, $6^{\circ} 35^{\prime} 25^{\prime \prime} \mathrm{S} 47^{\circ} 27^{\prime} 21^{\prime \prime W}, 150 \mathrm{~m}, 8$ March 2007, G. PereiraSilva $\mathcal{E}^{\circ}$ G. A. Moreira 11328 (CEN).

CONSERVATION STATUS. Based on its apparently very restricted area of occupancy and extent of occurrence (one of the cited localities is imprecise) this species would probably be assessed as Critically Endangered (CR). However, in the absence of any detailed understanding of its ecology or of its frequency in the two recorded populations, any formal categorisation would be premature and it should be categorised as Data Deficient (DD) until detailed studies can be carried out.

ETYMOLOGY. This species is named pogonocalyx because of the prominent spreading hairs on the abaxial surface of the sepals, an unusual feature of species in the Ipomoea mauritiana clade.

Ipomoea deminuta $J$. R. I. Wood $\mathcal{E}$ Scotland, sp. nov. Type: Bolivia, Santa Crux, Prov. Velasco, Camp. Flor de Oro, E. Gutiérrez, R. Quevedo Ẽ F. Mamani 1152 (holotype MO).

http:/ /www.ipni.org/urn:lsid:ipni.org:names:77160014-1

Slender twining herb of unknown height; stems pubescent. Leaves petiolate, $1.5-2.7 \times 0.4-1.2 \mathrm{~cm}$, lanceolate-deltoid, obtuse to acute, mucronate, base cordate, auricles variable, rounded, acute, or rounded with a prominent tooth, adaxially tomentose, abaxially grey-tomentose; petioles $3-7 \mathrm{~mm}$, densely pubescent. Inflorescence of very shortly pedunculate axillary flowers; peduncles $2-3 \mathrm{~mm}$, densely pubescent; bracteoles $3-4 \times 0.5-1 \mathrm{~mm}$, filiform, tomentose, persistent, \pm appressed to calyx; pedicels $0-1 \mathrm{~mm}$; sepals subequal, $7-8 \times 1-1.5 \mathrm{~mm}$, lanceolate, acute, densely pubescent, inner slightly narrower with scarious glabrous margins; corolla $2-2.5 \mathrm{~cm}$ long, pale pink, funnel-shaped, glabrous, limb c. $1 \mathrm{~cm}$ diam.; stamens included, stigma biglobose. Capsule and seeds not seen. Fig. 6.

RECOGNITION. This very slender species is quite unlike any other Ipomoea known to us. The small corolla, very small, tomentose, lanceolate-deltoid leaves, solitary flowers, short peduncles, persistent 


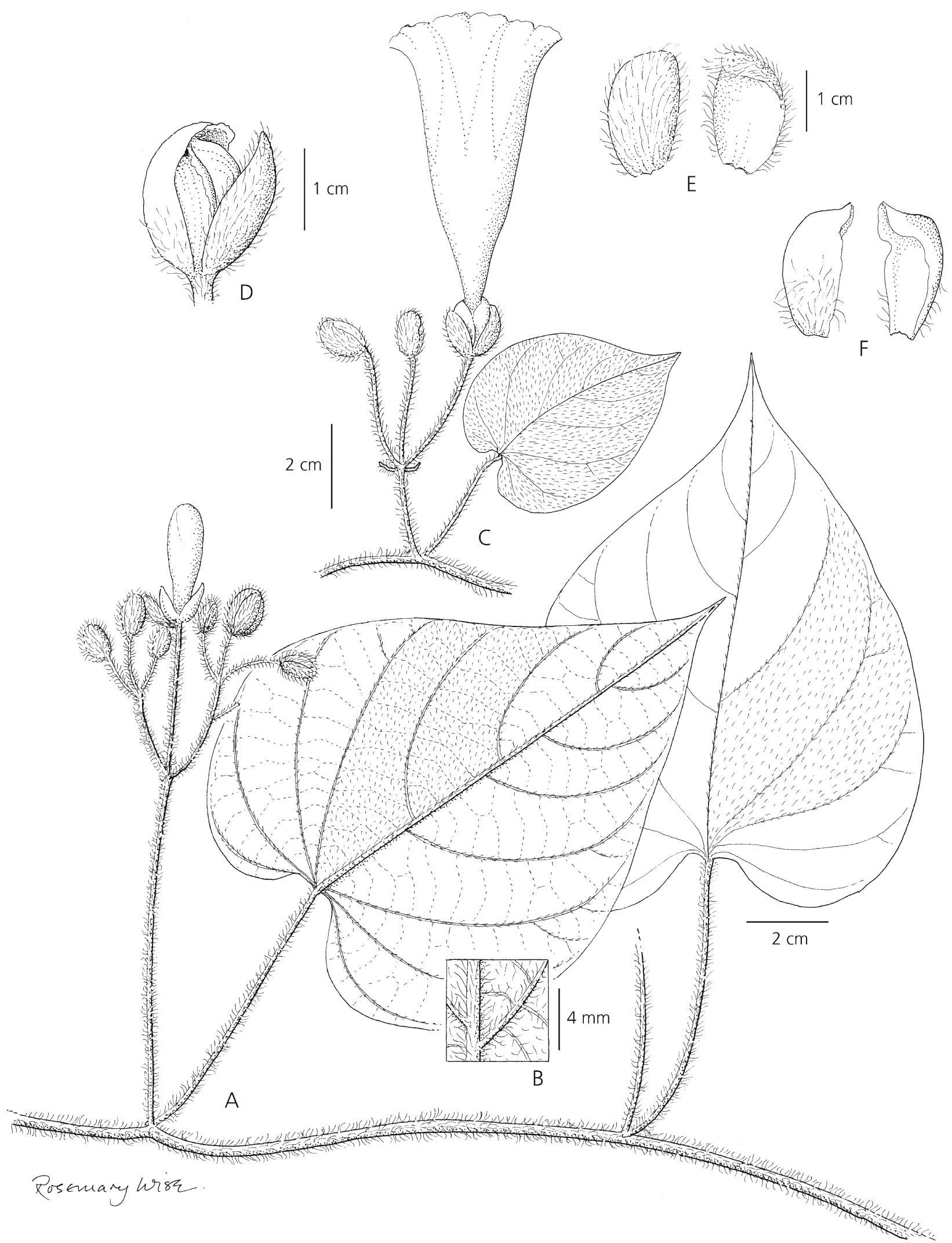

Fig. 5. Ipomoea pogonocalyx. A habit; B abaxial leaf surface; C inflorescence with corolla; D flower bud; E outer sepal, external (left) and internal (right) surfaces; F inner sepal, external (left) and internal (right) surfaces. A, D - F from J. U. Santos et al. 711; B C from G. Pereira-Silva \& G. A. Moreira 11328. DRAWN BY ROSEMARY WISE. 

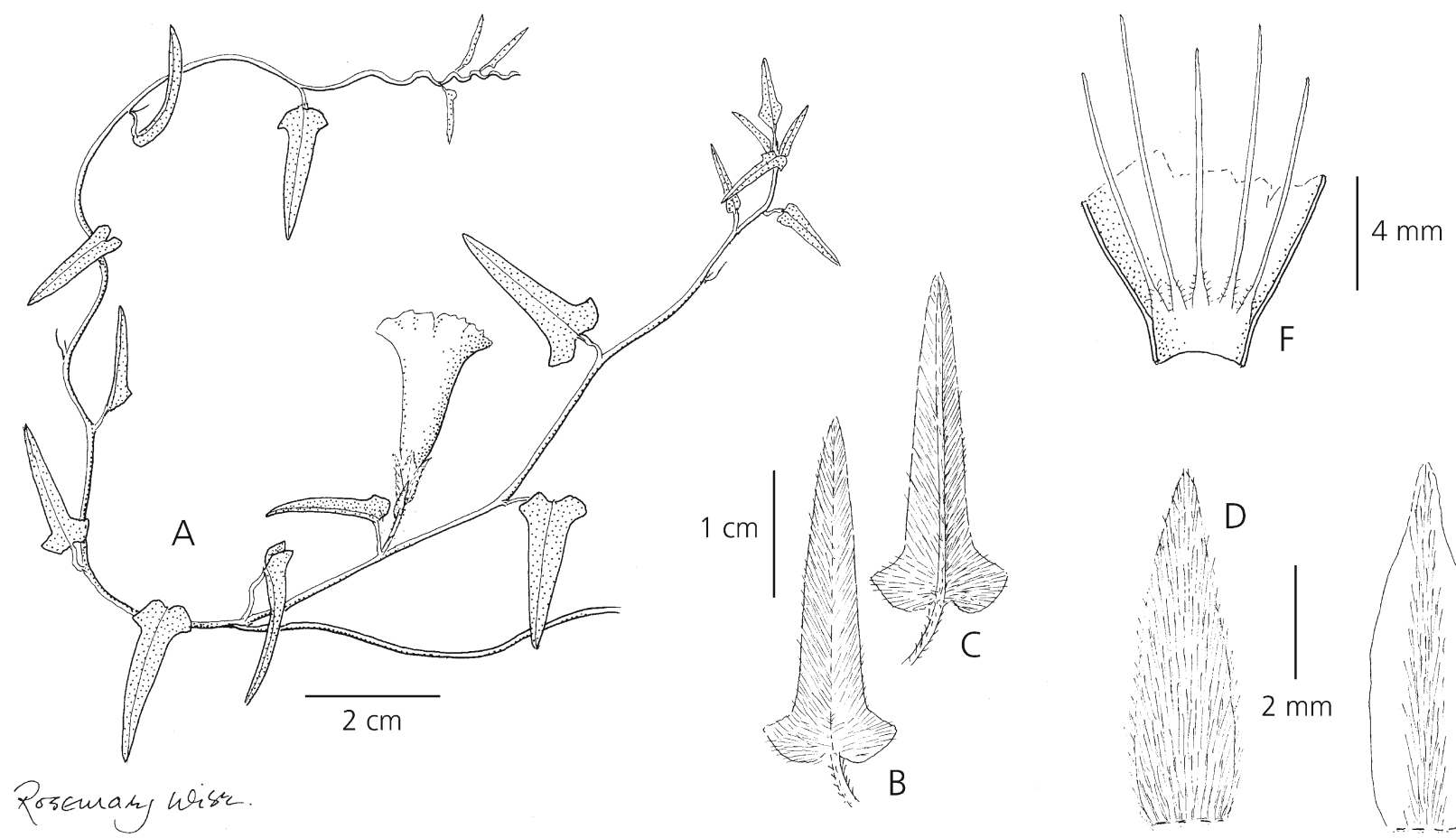

Fig. 6. Ipomoea deminuta. A habit; B adaxial leaf surface; C abaxial leaf surface; D outer sepal; E inner sepal; F corolla opened out to show insertion of filaments. From E. Gutiérrez et al. 1152. DRAWN BY ROSEMARY WISE.

bracteoles appressed to the calyx and suppressed pedicels all serve to separate it from all known species. Superficially it has some resemblance to the African I. convolvuloides Schinz but has a quite different inflorescence. Although we have not been able to sequence this species, we believe it is related to I. eriocalyx (= I. hewittacea (Kuntze) J. R. I. Wood \& Scotland). It is similar in indumentum and leaf shape, particularly in the variable leaf auricles. The suppressed pedicels are also suggestive of this relationship but $I$. deminuta differs in many ways, including the small dimensions of its leaves and flowers but especially in its very short peduncles and tiny bracteoles.

HABITAT \& DISTRIBUTION. Seasonally flooded pampa. Endemic to the Parque Noel Kempff Mercado in Bolivia, growing on the west bank of the Rio Iténez close to the frontier with Brazil (Map 2).

SPECIMEn eXamined. BoliviA. Santa Cruz: Prov. Velasco, PNNKM, Camp. Flor de Oro, Pampa húmeda SW del campamento, $13^{\circ} 33^{\prime} 03^{\prime \prime S} 61^{\circ} 03^{\prime} 31^{\prime \prime} \mathrm{W}, 200 \mathrm{~m}$, 25 May 1994, E. Gutiérrez, R. Quevedo E F F. Mamani 1152 (holotype MO).

CONSERVATION STATUS. The site of the only known collection of this species lies within the protected area of the Noel Kempff Mercado National Park. No information is known about the size of the population. Flooded pampa is a common habitat within and around this national park as also in adjacent parts of Brazil but as there is no informa- tion about the precise ecological requirements of this species, it is impossible to evaluate any threat that it may face. It can only be classified as Data Deficient (DD) in the absence of targeted searches to refind this species.

ETYMOLOGY. This species is named deminuta because of the small size of the plant in general, particularly its leaves, peduncles and pedicels.

\section{Ipomoea megapotamica}

Ipomoea megapotamica Choisy is the oldest name in a complex of species which includes I. sericophylla Meisn., I. hieronymi (Kuntze) O'Donell. I. argentinica Peter, I. longibarbis J. R. I. Wood \& Scotland, I. decipiens Dammer and several others. Most of these species have been described and discussed in Wood et al. (2015), where I. megapotamica was provided with a neotype in the absence of any original material or photograph of original material. The neotype ties this name to the form of this species found in Southern Brazil, Paraguay and Bolivia. This consistently differs from the form in NE Brazil in its minutely puberulent to scabridulous lower leaf surface; the abaxial surface of the leaves of plants from NE Brazil is almost always densely appressed pilose (Fig. 7J). Forms indistinguishable from the plant in NE Brazil are also found in Venezuela. We are, therefore recognising two geographical subspecies as set out below. 


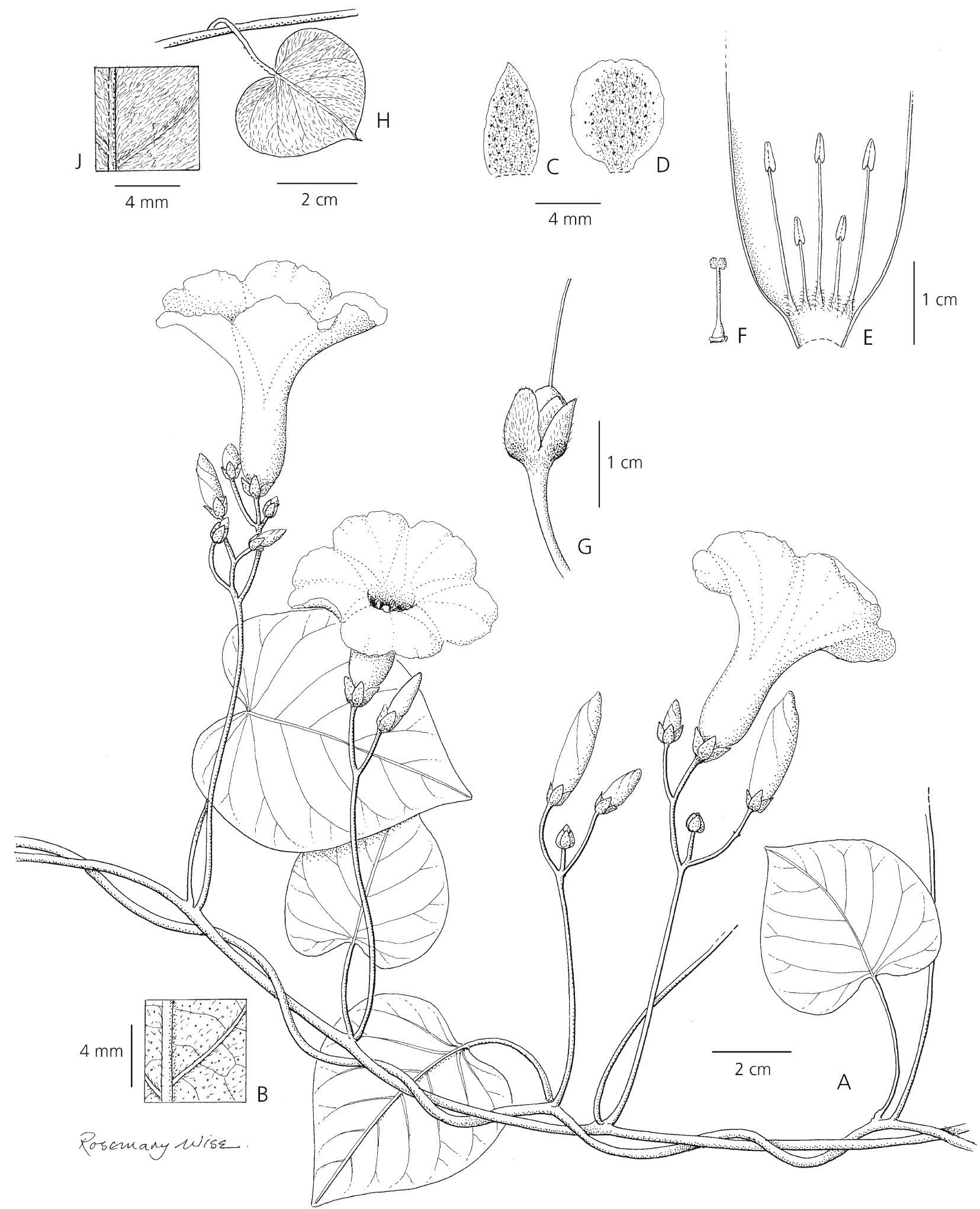

Fig. 7. Ipomoea megapotamica subsp. megapotamica. A habit; B abaxial leaf surface; C outer sepal; D inner sepal; E corolla opened out to show anthers; F ovary and style; G young fruit and calyx showing glands at base of sepals. Ipomoea megapotamica subsp. velutina. H leaf; J abaxial leaf surface. A - B from G. Hatschbach 23711; C - G from Fernández Casas \& Molero $4302 ; \mathrm{H}$ - J from A. Fernández-R et al. 9612. DRAWN BY ROSEMARY WISE. 
Ipomoea megapotamica Choisy (1845: 375) subsp. megapotamica. Type: "Uruguay", Otto s.n. (syntype B, not found, presumably destroyed in 1943), neotype: Brazil, Mato Grosso do Sul, G. Hatschbach 23711 (NY01013991, designated by Wood et al. 2015: 59; isoneotypes $\mathrm{F}, \mathrm{MBM}$ ).

Ipomoea megapotamica var. pauciflora Meisn. (Meisner 1869: 259). Type: Southern Brazil, Sello s.n. (whereabouts unknown).

Argyreia megapotamica var. puberula Griseb. (Grisebach 1879: 263). Type: based on Ipomoea megapotamica Choisy.

Ipomoea megapotamica var. cordifolia Hassl. (Hassler 1911: 157). Type: Paraguay, Concepción, Naranjati, E. Hassler 10401 (lectotype G00175106, designated here).

Ipomoea vivianae Krapov. p.p. (Krapovickas 2009: 57).

Subsp. megapotamica is characterised by the abaxial surface of the leaves minutely puberulent to scabridulous. Fig. 7A - G.

DISTRIBUTION \& HABITAT. This subspecies has a circumChaco distribution being found in Bolivia, Paraguay and Brazil, where it grows on the edges of seasonally dry forest. Map 3.

CONSERVATION STATUS. Least Concern (LC).

NOTES. The type and some paratypes of Ipomoea vivianae Krapov. represent an apparently distinct species distinguished from I. megapotamica by the nearly glabrous leaves, usually white corolla, distinctly corky stems and, in particular, the often raceme-like inflorescence that develops on short shoots. However, many of the cited paratypes (Krapovickas 2009) including all we have seen from the Amambay region of Paraguay are I. megapotamica subsp. megapotamica.

Wood et al. (2015) treated Ipomoea subalata Hassl. as a synonym of $I$. megapotamica. We now believe this to have been a mistake. Re-examination of images of the type of $I$. subalata shows a plant with similar corolla, sepal and leaf indumentum to I. megapotamica but the sepals are larger and similar in form to those of I. chondrosepala Hallier $\mathrm{f}$. It fits neither species very well and its exact identity cannot be resolved without further collections from NE Paraguay.

Ipomoea megapotamica subsp. velutina $J$. R. I. Wood $\mathcal{E}^{\circ}$ Scotland, subsp. nov. Type: Brazil, Pernambuco, Tapera, Aug. 1933, B. Pickel 3037 (holotype RB00263114; isotypes NY, P).

http://www.ipni.org/urn:Isid:ipni.org:names:60473795-2

Ipomoea nyctaginea var. cordifolia Choisy (1845: 369). Type: Brazil, Piahu, Martius 2482 (lectotype M0185009, designated here).

Subsp. velutina is characterised by the densely adpressed pilose abaxial surface of the leaves, the hairs long and conspicuous. Fig. $7 \mathrm{H}-\mathrm{J}$.

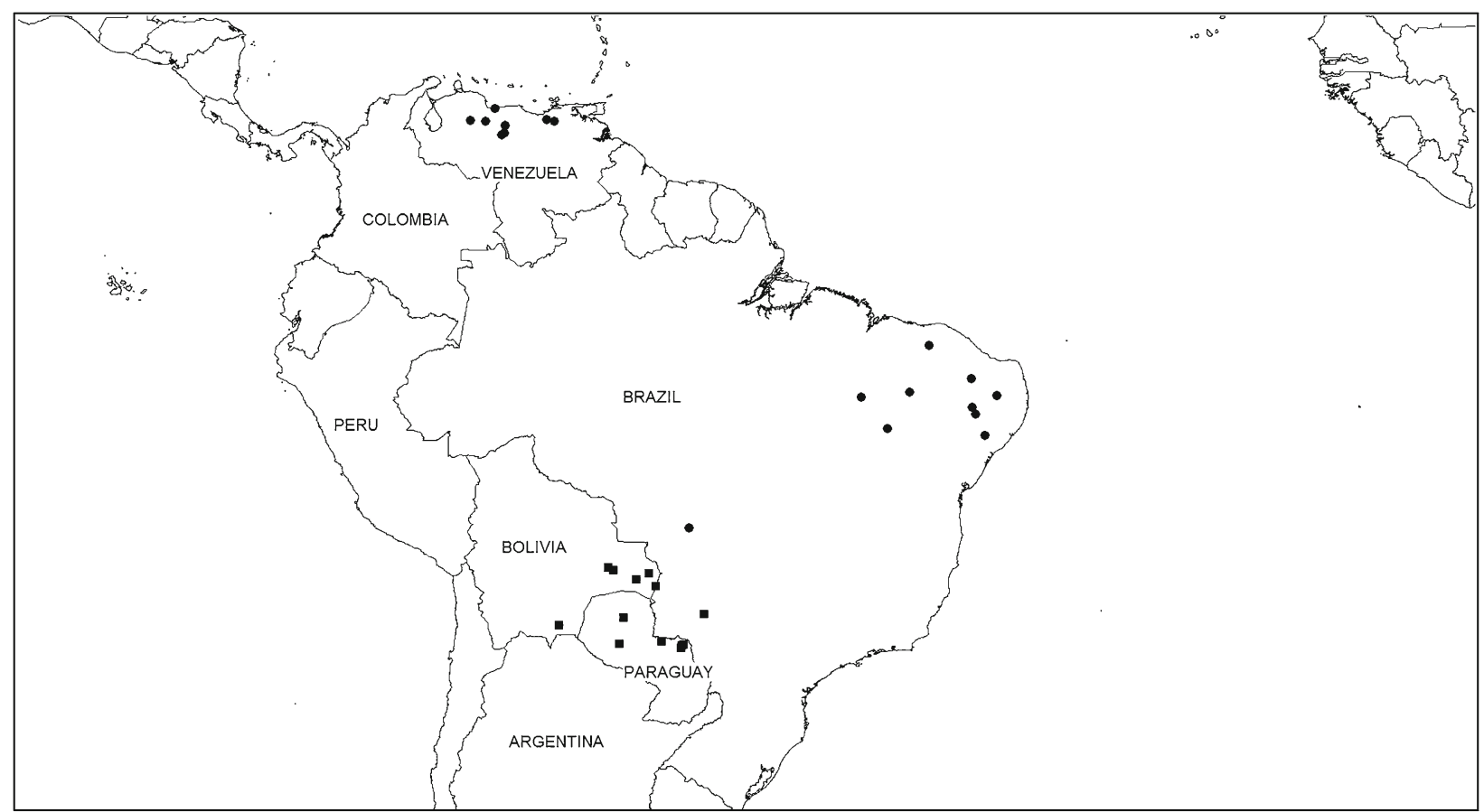

Map 3. Distribution of Ipomoea megapotamica subsp. megapotamica ( $\bullet$ ) and subsp. velutina (•). 
TYPIFICATION. There are two specimens of Martius 2482 at Munich but we are designating M0185009 as the lectotype of Ipomoea nyctaginea var. cordifolia as it is annotated "Ip nyctaginea. $\beta$ (Choisy)" in a different hand from the label, possibly that of Choisy. The other specimen (M0185010) bears only the original annotation "Ipom. subrepanda" and may not have been seen by Choisy even though it is a better specimen and was labelled as holotype by McDonald in 1982.

We have treated this subspecies as a new subsp. velutina to avoid confusion between Ipomoea megapotamica var. cordifolia Hassl. and I. nyctaginea var. cordifolia Choisy which represent different taxa.

DISITRIBUTION \& HABITAT. Dry forest (caatinga) and scrub in NE Brazil and Venezuela. Map 3.

SELECTED SPECIMENS EXAMINED. BRAZIL. Alagoas: Pão de Azucar, $9^{\circ} 42^{\prime} \mathrm{S} 37^{\circ} 30^{\prime} \mathrm{W}$, 22 June 2002, Lyra-Lemos et al. 6889 (RB). Ceará: Planalto de de Ibíapaba, Mun. de Carnaubal, $4^{\circ} 10^{\prime} \mathrm{S} 40^{\circ} 55^{\prime} 30^{\prime \prime} \mathrm{W}, 30$ April 2010, E. B. Souza 1842 (UFR). Maranhão: 5 April 1962, Mun. Loreto, $7^{\circ} 21^{\prime} \mathrm{S} 45^{\circ} 7-8^{\prime} \mathrm{W}$, G. E $~ L$. T. Eiten 4051 (US). Mato Grosso: Chapada dos Guimarães, Feb. 1995, B. Dubs 1840 (ARIZ, S, Z). Paraiba: 25 May 1959, Coêlho de Moraes 2126 (MO, US). Pernambuco: Tapera, 8²4'S $38^{\circ} 05^{\prime} \mathrm{W}$, Aug. 1933, B. Pickel 3037 (holotype RB; isotypes NY, P); Serra Talhada, $7^{\circ} 59^{\prime} \mathrm{S} 38^{\circ} 17^{\prime} \mathrm{W}$, April 1971, E. P. Heringer et al. s.n. (RB). Piauí: Caracol, P.N. Serra das Confusões, $9^{\circ} 15^{\prime} 51^{\prime \prime S} 43^{\circ} 29^{\prime} 40^{\prime \prime} \mathrm{W}, 10$ April 2009, G. Martinelli et al. 16358 (RB). Rio Grande do Norte: Agua Nova, $6^{\circ} 13^{\prime} \mathrm{S} 38^{\circ} 21^{\prime} \mathrm{W}$, A. C. Sarmento 761 (K, RB). Venezuela. Portuguesa: Araure, orillas del Rio Auro, $9^{\circ} 43^{\prime} \mathrm{N} 69^{\circ} 16^{\prime} \mathrm{W}, 300 \mathrm{~m}, 13$ Sept. 1984, G. Aymard Eं F. Ortega 3078 (NY). Guarico: Mesa de el Sombrero, H. Pittier 12486 (US). Cojedes: Las Peonías, 26 Sept. 1975, Delascio 3401 (FTG). Monagas: Mun. Freitas, $10 \mathrm{~km}$ al E de Úrica, $9^{\circ} 39^{\prime} \mathrm{N} 64^{\circ} 04^{\prime} \mathrm{W}, 360 \mathrm{~m}$, Oct. 1996, A. Fernández-R et al. 9612 (US).

CONSERVATION STATUS. Least Concern (LC). However, we have very little information about the size or status of populations in Venezuela so it might be best to treat this species as Data Deficient (DD) in that country. NOTES. The two subspecies are readily recognisable and are geographically separate although Dubs 1840 could be interpreted as intermediate geographically and morphologically but is certainly closer to subsp. velutina. More controversial is the delimitation of species related to Ipomoea megapotamica. Austin (1982) considered the Venezuelan specimens cited above to belong to I. subsericea Meisn. but we regard that species as restricted to Minas Gerais and Goías in Brazil and distinct on account of the absence of conspicuous glands on the sepals, which are acute, not mucronate, and more densely tomentose. The peduncles are also shorter so the cymes are exceeded by the leaves. Although we accept that species delimitation is difficult in this complex and that some intermediates may occur, any attempt to unite all related species will result in an unsatisfactory, counter-intuitive aggregate. I. megapotamica is any case the oldest name in this complex.

Ipomoea subsericea should be deleted from the list of species occurring in Venezuela. All records from Venezuela appear to belong to I. megapotamica subsp. velutina.

\section{Ipomoea chenopodiifolia and I. retropilosa}

The earliest reference to the occurrence of Ipomoea chenopodiifolia in South America that we have found is on herbarium sheets annotated by O'Donell in 1953 under the name I. signata House, now generally accepted as a later synonym of $I$. chenopodiifolia (M. Martens \& Galeotti) Hemsl. I. chenopodiifolia remains an accepted species for Venezuela (for example, Austin et al. 2012) although the Venezuelan populations are very disjunct from the main populations in Guatemala and Chiapas and doubts were raised almost 30 years ago by McDonald (1987: 57) about the correct identity of the Venezuelan plants.

There are very few collections of Ipomoea chenopodiifolia from Venezuela (see below) and on examination these proved indistinguishable from I. retropilosa (Pittier) D. F. Austin, itself a poorly known species. Austin (1982) distinguished the two species by the shape of the corolla, claiming that I. retropilosa could be separated by its funnel-shaped corolla from I. chenopodiifolia with its hypocrateriform corolla with exserted stamens. I. retropilosa, in fact, has a hypocrateriform corolla and it is difficult to explain Austin's error as Pittier (1931: 143) clearly describes the corolla of $I$. retropilosa as characterised by "tubo recto, limbo subplano ...staminibus ..longe exsertis..." except by the fact that none of the isotypes in North American herbarium show the corolla clearly; the hypocrateriform corolla can only be easily seen on the Geneva isotype, which appears to be the only type number with a corolla.

All Venezuelan specimens named Ipomoea chenopodiifolia or I. signata conform closely to the type of I. retropilosa, which we regard as the correct name for these Venezuelan plants. They all differ from material of I. chenopodiifolia from Chiapas and Guatemala by the indumentum as well as the shape and size of the sepals, which are hirsute, subequal, broadly ovate but never more than $9 \mathrm{~mm}$ long, rather than glabrous, distinctly unequal, lanceolate to narrowly ovate with the inner sepals up to $13 \mathrm{~mm}$ long (Fig. 8E). I. chenopodiifolia should be deleted from the list of species known from Venezuela.

Ipomoea retropilosa (Pittier) D. F. Austin (1977[pub. 1978]: 337).

Exogonium retropilosum Pittier (1931: 143). Type: Venezuela, Mérida, Timotes, 2000 m, 23 Jan. 1928, 


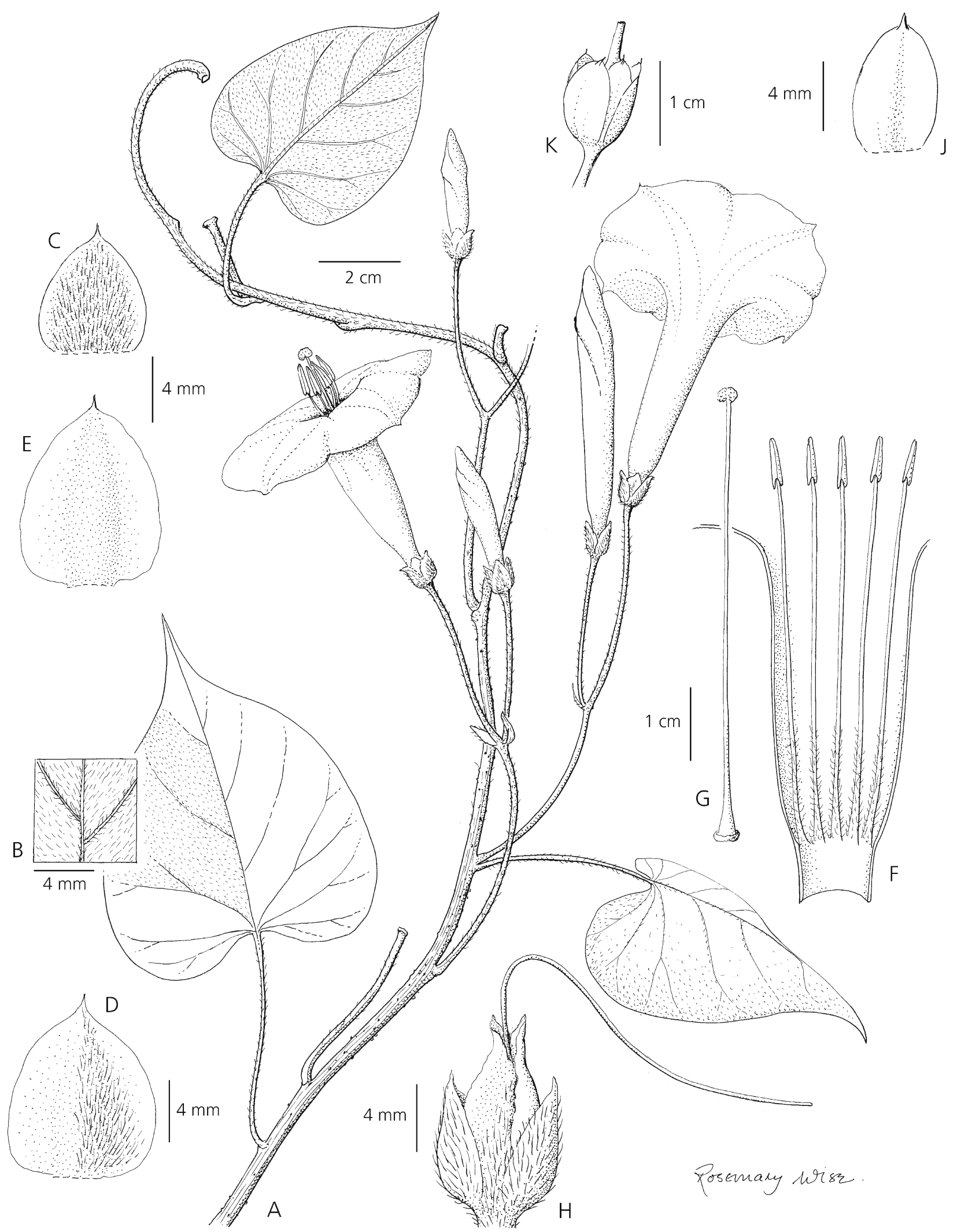

Fig. 8. Ipomoea retropilosa subsp. retropilosa. A habit; B abaxial leaf surface; C outer sepal; D middle sepal; E inner sepal; F corolla opened out to show stamens; $\mathrm{G}$ ovary, style and stigma; $\mathrm{H}$ young fruiting calyx. I. retropilosa subsp. cundinamarcana. J outer sepal; K calyx with rostrate apex to capsule. A - H from J. B. Simmons 281; J - K from André S.n. DRAWN BY ROSEMARY WISE. 


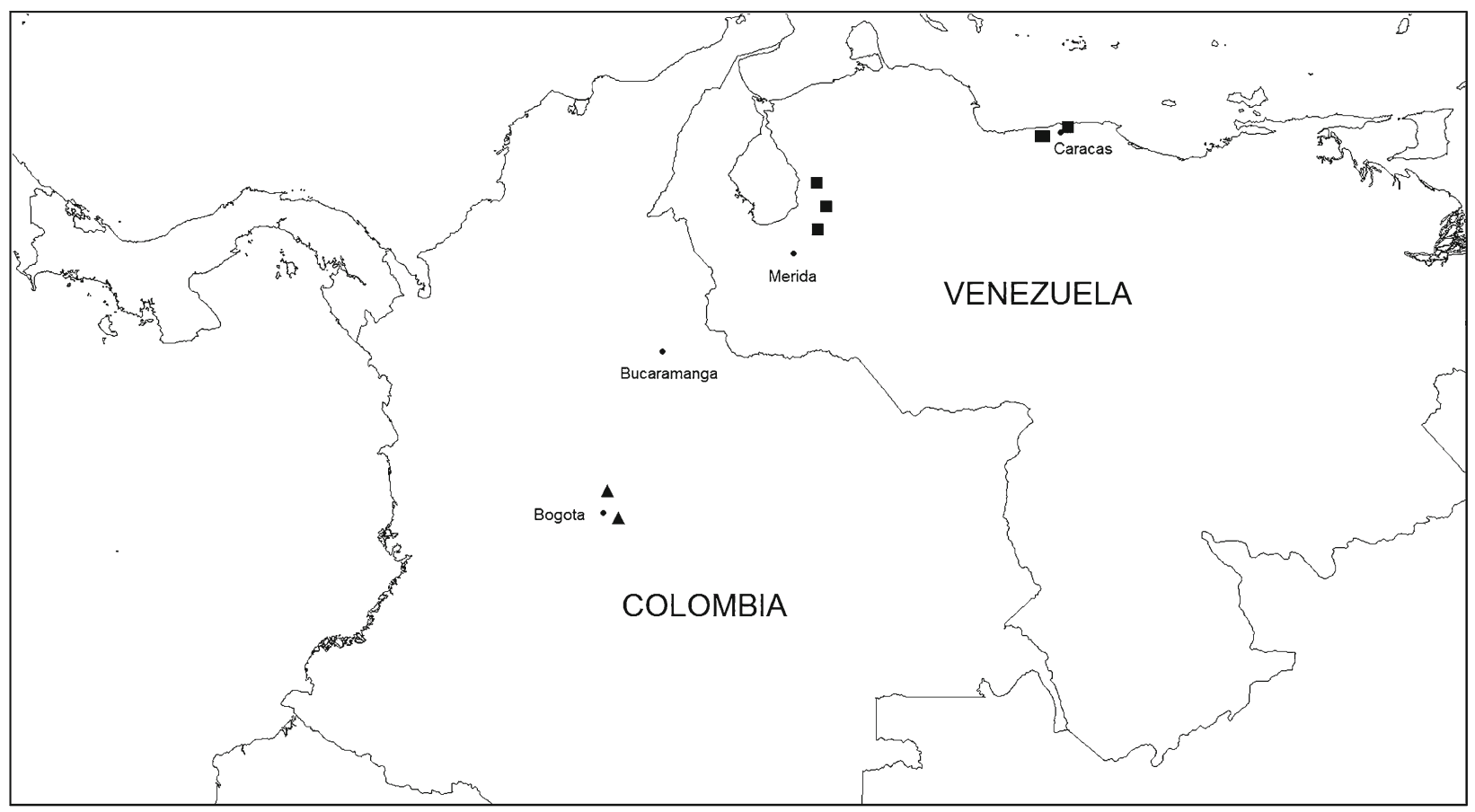

Map 4. Distribution of Ipomoea retropilosa subsp. retropilosa ( $\mathbf{\square})$ and subsp. cundinamarcana ( $\mathbf{\Delta}$ ).

H. Pittier 12698 (holotype VEN!; isotypes F!, G!, MO!, US!).

Ipomoea signata sensu Austin (1982) et I. chenopodiifolia sensu Austin \& Huáman (1996) quoad records from South America.

HABITAT \& DISTRIBUTION. Apparently growing in cloud forest near streams in the coastal sierra of Venezuela between 1500 and $1800 \mathrm{~m}$ approximately. Map 4 .

SPECIMENS EXAMINED. VENEZUELA. Mérida, Colonia Tovar, 1865, Moritz 1686 (BM, K); $8 \mathrm{~km} \mathrm{~S}$ of Timote[s], 1976, J. B. Simmons 281 [K], Distrito Ricaurte, 3 km E of Colonia Tova[r], 10 ${ }^{\circ} 24^{\prime} \mathrm{S} 67^{\circ} 14^{\prime} \mathrm{W}, 1800-1850 \mathrm{~m}$, J. A. Steyermark E̋ R. L. Liesner 121997 (MO); Trujillo, Varela, 1500 m, L. Aristeguieta 4884 (MO).

CONSERVATION STATUS. Based on an area of occurrence of slightly more than $17,000 \mathrm{~km}$ this species might be classified as Vulnerable (VU) but based on an area of occupancy of $24,000 \mathrm{~km}^{2}$ it might be classified as Endangered (EN). Given the relative accessibility of the cloud forest in Andean Venezuela over more than 150 years and the paucity of records, the categorisation of Endangered (EN) would seem correct, particularly as several of the recorded sites lie near centres of population. Some populations may lie within one or more of the protected areas established in Andean Venezuela but this requires confirmation.

NOTE. Map 4 shows the somewhat disjunct populations of Ipomoea retropilosa in Venezuela. Although there is variation in the density of the indumentum, no clear geographical patterning in this variation was observed. Plants nearly identical to Ipomoea retropilosa also grow very locally in Colombia but differ in the completely glabrous sepals. In the absence of any other discernible differences we treat this distinct population as a subspecies as follows:

Ipomoea retropilosa subsp. cundinamarcana $J$. R. $I$. Wood E Scotland, subsp. nov. Type: Colombia, Cundinamarca, Quebrada el Chico, al norte de Bogotá, 2700 - 2800 m, 30 Nov. 1952, H. Humbert, J. Idrobo $\mathcal{E} \mathcal{F}^{2}$. Jaramillo 27532 (holotype P03538230).

http:/ /www.ipni.org/urn:lsid:ipni.org:names:77160015-1

RECOGNITION. Subsp. cundinamarcana is distinguished from subsp. retropilosa by its completely glabrous sepals. The young stems and abaxial surface of the leaves are also glabrous. Fig. 8J.

HABITAT \& DISTRIBUTION. No details are known of the plant's habitat but it is only known from the Eastern Cordillera of Colombia in Cundinamarca from two records. It is likely to be a cloud forest species and is obviously rare and endemic to this area of Colombia. The only cited altitude is $2700-2800 \mathrm{~m}$, significantly higher than the recorded locations of subsp. retropilosa in Venezuela. 
SPECIMENS EXAMINED. COLOMBIA. Cundinamarca, north of Bogotá, 30 Nov. 1952, Humbert et al. 27532 (P); "Villavicencio?", [1875 - 6], E. André 137 (K).

CONSERVATION STATUS. This subspecies is only known from two collections, the most recent made over 60 years ago. It might possibly be extinct but is more probably Endangered (EN). Although the cloud forests of Colombia's Eastern Cordillera have been much reduced, much still survives and it is highly likely that targeted searching will reveal surviving populations.

NOTES. The glabrous sepals of subsp. cundinamarcana mean that this subspecies can only be reliably distinguished from Ipomoea chenopodiifolia by the subequal, broader, ovate sepals less than $9 \mathrm{~mm}$ in length.

This species (and its subspecies) are not accounted for in the recent Catalogue of Colombian plants (Bernal et al. 2015). However it is quite likely that there is an isotype in the Colombian national herbarium (COL) as the holotype was collected in the company of two Colombian botanists.

\section{Ipomoea austinii}

Ipomoea austinii Infante-Bet. was recently described from NE Colombia based on a single collection (Infante-Betancour 2014). The author compared it with a number of American species but was unable to recognise any obvious affinities. This is unsurprising as the plant is the very distinctive African I. involucrata P. Beauv. as can be clearly seen from the good illustration that accompanies the paper. The plant was collected once from an oil palm plantation and was perhaps introduced to Colombia with the oil palm plants. The synonymy is set out below:

Ipomoea involucrata $P$. Beauv. (Palisot de Beauvois 1816: 52). Type: Nigeria, Oware, P. de Beauvois (holotype G00023040).

Convolvulus perfoliatus Schumach. \& Thonn. (Schumacher \& Thonning 1827: 89). Type: Ghana, Thonning s.n. (syntypes C).

Ipomoea austinii Infante-Bet. (Infante-Betancour 2014: 248). Type: Colombia, Cesar, San Alberto, $M$. Carillo-F. 557 (holotype COL).

There is evidence for a number of introductions of Ipomoea from the Old World. I. rubens Choisy may have been introduced in pre-historic times as it gives every appearance of being native in the neotropics. I. cairica (L.) Sweet, I. obscura (L.) Ker-Gawl. and I. ochracea (Lindl.) G. Don have long been naturalised. I. tiliifolia
(Desr.) Roem. \& Schult. is well-established in the Galapagos Islands. More recent introductions include I. eriocarpa R. Br. in Puerto Rico and now I. involucrata in Colombia.

\section{Acknowledgements}

We are grateful for the loan of material from ARIZ, BM, F, FTG, K, MO, NY, P, RB and US, which has made this paper possible. Thanks are due to Rosemary Wise for preparing the illustrations of the new species. We acknowledge the financial support of the Leverhulme Foundation for funding our Ipomoea Foundation Monograph project and also an NERC IAA award for the illustrations. María Teresa Buril (PEUFR) has helped improve the manuscript with useful comments.

Open Access This article is distributed under the terms of the Creative Commons Attribution 4.0 International License (http://creativecommons.org/licenses/by/4.0/ ), which permits unrestricted use, distribution, and reproduction in any medium, provided you give appropriate credit to the original author(s) and the source, provide a link to the Creative Commons license, and indicate if changes were made.

\section{References}

Austin, D. F. (1977 [pub. 1978]). Realignment of the species placed in Exogonium (Convolvulaceae). Ann. Missouri Bot. Gard. 64: 330 - 339.

(1982). Convolvulaceae. In: Z. Luces de Febres \& J. A. Steyermark (eds), Flora of Venezuela 8: 15 - 226. Fundación Instituto Botánico de Venezuela, Caracas. \& Huáman Z. (1996). A synopsis of Ipomoea (Convolvulaceae) in the Americas. Taxon 45: 3 38.

, McDonald, J. A. \& Murguía-Sánchez, G. (2012). Convolvulaceae. In: Flora Mesoamericana 4 (2): 318 352. Universidad Nacional Autónoma de México, Missouri Botanical Garden, St. Louis and The Natural History Museum, London.

\& Staples, G. W. (1991). A revision of the Neotropical species of Turbina Raf. (Convolvulaceae). Bull. Torrey Bot. Club 118 (3): 265 - 280.

Bernal, R. Gradstein, S. R. \& Celis, M. (2015). Catálogo de plantas y líquenes de Colombia. Instituto de Ciencias Naturales, Universidad Nacional de Colombia, Bogotá. www.catalogoplantascolombia.unal.edu.co

Choisy, J. D. (1845). Convolvulaceae. In: A. P. de Candolle (ed.), Prodromus Systematis Naturalis 9: 323 - 462. Fortin, Masson \& Co, Paris.

Dammer, U. (1897). Convolvulaceae. In: I. Urban, Plantae novae americanae imprimis Glaziovianae 1. Bot. Jahrb. Syst. 23, beibl. 57: $36-42$. 
Grisebach, A. H. R. (1879). Symbolae ad floram argentinam. Abh. Königl. Ges. Wiss. Göttingen, Math.Phys. Kl. 19: 49 - 278.

Hassler, E. (1911). Ex Herbario Hassleriano: Novitates paraguariensis X11. Repert. Spec. Nov. Regni Veg. 9: 145 - 160.

Infante-Betancour, J. (2014). Una nueva especie de Ipomoea (Convolvulaceae) para Colombia. Caldasia 36(2): $247-252$.

Krapovickas, A. (2009). Novedades en Convolvuláceas argentinas. Bonplandia 18(1): 57 - 64 .

McDonald, J. A. (1987). Revision of Ipomoea section Exogonium (Choisy) Griseb. (Convolvulaceae). Brenesia 28: 41 - 87.

Meisner, C. F. (1869). Convolvulus. In: C. Martius, Flora Brasiliensis 7: 200 - 424. Fleischer, Leipzig.
Muñoz, P. et al. (in prep.). Insights into Ipomoea s.l. based on molecular studies.

Palisot de Beauvois, A. M. F. J. (1816). Flore d'Oware et de Bénin, Vol. 2, part 15: 45 - 52. Paris.

Pittier, H. (1931). Botanical notes on and descriptions of new and old species of Venezuelan plants. - IV Berberis in Venezuela, new species of Oxalis, Exogonium and others. J. Wash. Acad Sci $21(7): 134-143$.

Schumacher, C. F. \& Thonning, J. (1827). Beskrivelse af Guineeiske planter. Copenhagen.

Wood, J. R. I., Carine, M. A., Harris, D., Wilkin, P., Williams, B. \& Scotland, R. W. (2015). Ipomoea (Convolvulaceae) in Bolivia. Kew Bull. 70(31): 1 124. doi:10.1007/512225-015-9592-7. 